\title{
鉄リン酸塩ガラスの電気的性質と内部摩擦
}

\author{
土谷敏雄・音成光哉・有山堯* \\ ( 東京理科大学 理工学部 工業化学科) \\ *東京理科大学 工学部 機械工学科
}

\section{Electrical Properties and Internal Friction in Iron Phosphate Glasses}

\author{
Toshio TSUCHIYA, Mitsuya OTONARI and Takashi ARIYAMA* \\ Department of Industrial Chemistry, Faculty of Science and Technology, Science University of Tokyo \\ Yamazaki, Noda-shi 278 \\ * Department of Mechanical Engineering, Faculty of Technology, Science University of Tokyo
}

\begin{abstract}
The internal friction and electrical properties of glasses in $40 \mathrm{Fe}_{2} \mathrm{O}_{3} \cdot 60 \mathrm{P}_{2} \mathrm{O}_{5}$ system were measured. The quantitative values of dynamic modulus $G^{\prime}$ and dynamic loss $G^{\prime \prime}$ on internal friction were obtained by considering the shape factor. $G^{\prime}$ was 3.0 $\times 10^{9}-1.0 \times 10^{10} \mathrm{dyn} / \mathrm{cm}^{2}$, and $G^{\prime \prime}$ was $1.0 \times 10^{7}-5.0 \times 10^{7} \mathrm{dyn} / \mathrm{cm}^{2}$ in the range of valence ratio $\left(R_{e}=\mathrm{Fe}^{2+} / \mathrm{Fe}^{2+}+\right.$ $F^{3+} e^{3} R_{e}=0.13$ to $R_{e}=0.37$. The two peaks were observed in the temperature range from $-100^{\circ}$ to $400^{\circ} \mathrm{C}$ at a frequency of about $1 \mathrm{~Hz}$. The area of the low temperature peak (at about $0^{\circ} \mathrm{C}$ ) increased with increasing valence ratio $R_{e}$ similar to that in the D.C. conductivity and dielectric increment. All of internal friction peak and electrical properties showed maxima at $R_{e}=0.5$. Frequency temperature dependence of the dielectric loss peak and low temperature peak on internal friction showed a straight line and its activation energy was $0.55 \mathrm{eV}$. The internal friction peak in glasses of $40 \mathrm{MgO}^{\circ} 60 \mathrm{P}_{2} \mathrm{O}_{5}$ system was not observed in the temperature range $-100^{\circ}$ to $200^{\circ} \mathrm{C}$. From the above results the peak observed at low temperature was due to the hopping of localized electron in small polaron. On the other hand, the activation energy of high temperature peak was about $1.6 \mathrm{eV}(37 \mathrm{kcal} / \mathrm{mol})$ and the high temperature peak decreased with increasing $R_{e}$ ratio. Consequently, the peak observed at high temperature was considered as due to the interaction between proton and non-bridging oxygen ions.
\end{abstract}

[Received January 20, 1986]

Key-words : Iron-phosphate glasses, Internal friction, D. C. conductivity, Dielectric properties, Complex modulus

\section{1. 緒 論}

鉄を多量に含有するリン酸塩ガラスは，典型的なホッ ピング電導を示すことが知られている．鉄リン酸塩ガラ スの直流導電率は, 鉄イオンの原子価比 $\left(\mathrm{Fe}^{2+} / \mathrm{Fe}^{2+}+\right.$ $\left.\mathrm{Fe}^{3+}\right)$ が 0.5 のとき,すなわち, $\mathrm{Fe}^{2+}$ イオンと $\mathrm{Fe}^{3+}$ イ オンの数が等しいときに極大を示す ${ }^{1,2)}$. その導電機構 を解明するためには，電荷の短距離移動を解析できる誘 電緩和の測定が有効である.鉄リン酸塩ガラスの誘電緩 和強度は, 直流導電率と同样に鉄イオンの原子価比が 0.5 のとき，極大を示した ${ }^{3)}$. しかし，誘電緩和の測定 の場合超低周波数領域の測定が, 技術的に非常に困難で ある. それに比べ, 応力緩和の測定は超低周波数領域の 測定が容易であり, $1 \mathrm{~Hz}$ 前後における電荷の挙動を直 接とらえることが可能である. 応力緩和の測定の一手段 として内部摩擦がある.内部摩擦の測定はアルカリを含 むガラスについて多くの研究がなされている が4 6), 遷移金属を含む電子伝導性ガラスについては二, 三の研究がなされているのみである77,8).そこで, 本研 究は精密に作製した内部摩擦装置を用いて, コンピュー ターによる自動化を試み，以前報告した鉄リン酸塩ガラ スの内部摩擦 ${ }^{3}$ のデー夕の検討を行い，またその定量化
を試みた。従来までの測定は, ほとんど, 内部摩擦 $\left(Q^{-1} \times 10^{3}\right)$ の温度依存性のみであり, そのため, 定量 的な議論は, 不可能であった。本報告では, 特に試料の 形状因子を考虑した， $G^{\prime}$ (動的弾性率)， $G^{\prime \prime}$ (損失弾性 率) の温度依存性を測定し, 定量的な議論を試みた。更 $に$, 内部摩擦 $\left(Q^{-1} \times 10^{3}\right)$ 之電気的性質 (直流導電率, 誘電特性) との関連性について検討した。

\section{2. 実験方法}

\section{1 試料の作製}

原料として特級試薬の酸化第二鉄 $\left(\mathrm{Fe}_{2} \mathrm{O}_{3}\right)$, リン酸 $\left(\mathrm{H}_{3} \mathrm{PO}_{4}\right)$ いずれも和光純薬工業製を用いた。 40 $\mathrm{Fe}_{2} \mathrm{O}_{3} \cdot 60 \mathrm{P}_{2} \mathrm{O}_{5}$ の組成に原料を調合し, アルミナるつぼ に移し, 焼結後 $1200^{\circ} \mathrm{C} て ゙ ~ 2 \mathrm{~h}$ 溶融した. また, 試料中 の $\mathrm{Fe}^{2+} / \mathrm{Fe}^{2+}+\mathrm{Fe}^{3+}$ 比は, バッチ組成にカーボンを添 加して溶融することにより調節した。溶融したガラスを 直径 $40 \mathrm{~mm}$, 厚さ $3 \sim 4 \mathrm{~mm}$ の円盤状のステンレスの型 に流し, 除歪後, 両面を研磨し, 3 電極配置に金を蒸着 したものを電気的測定用試料とした. 更に同じるつぼか ら石英棒を引き上げ直径 $1 \mathrm{~mm}$, 長さ $40 \mathrm{~mm}$ のファイ バー状試料を作り, 内部摩擦測定用試料とした。 


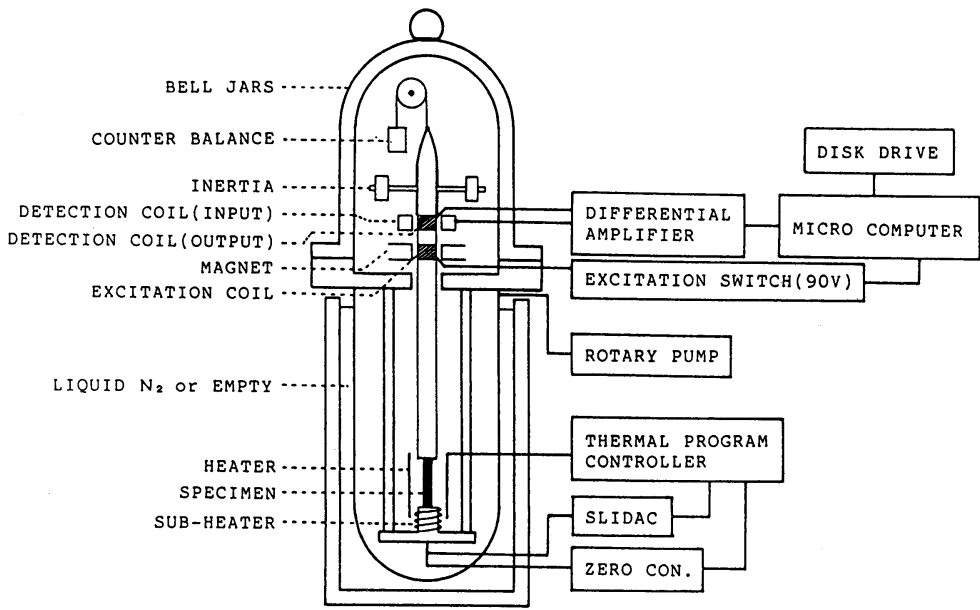

Fig. 1. Measuring apparatus of internal friction.

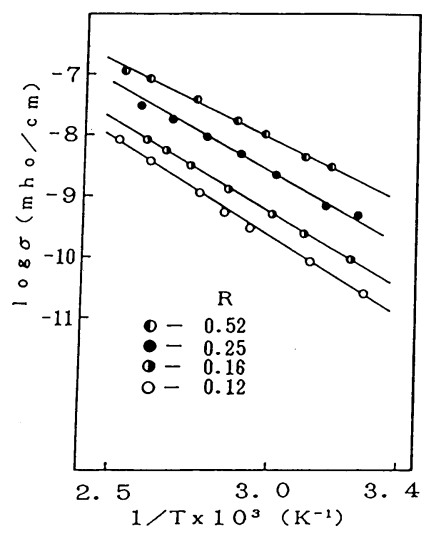

Fig. 2. Temperature dependence of D.C. conductivity in the glasses of $40 \mathrm{Fe}_{2} \mathrm{O}_{3} \cdot 60 \mathrm{P}_{2} \mathrm{O}_{5}$.

\section{2 直流導電率及び誘電特性の測定}

直流による導電率の测定は, 振動容量型直流増幅器 (夕 ケダ理研製, TR-84 M) を用いた電流電圧法で, $30-10^{6} \mathrm{~Hz}$ 域の交流測定は, 変成器ブリッジ(安藤電気製, TR-1 C) を用いて行った. 測定方法及びデータの整理 の仕方は，既報のとおりである ${ }^{9)}$.

\section{3 内部摩擦測定}

内部摩擦の測定は, 図 1 に示すような逆つり型ねじり 振り子で行った。、マイクロコンピューター（富士通製, FM-8）で定期的に励起コイルに対して電流を流す.コ イルの回りには磁石が固定してあるため，振り子に対し て, ねじり振動が加わる. 励起スイッチを切ると, 試料 下部が固定されているため, 試料の振動のみが振り子を 振らせる. その振動を検出コイルで読みとり, 差動アン
プで増幅した後，コンピューター (A-D コンバーター で読み取る）で対数減衰率 $(\Delta)$ 及び周期 $(T d)$ を計算 してディスクに記録した. なお，振り子は，その重さが 試料に対してかからないようにするために，カウンター バランスで釣り合いをとる．測定中，系内は油回転真空 ポンプ (丸山真空製，GP-100）で真空を保った。 ヒー ターにはニクロム線を使用し, 炉が縦型炉であるために， メインヒーターと補助ヒーターの二つのヒーターを用い 温度プログラムコントローラー (真空理工製, HPC-5000) によって PID 制御をし温度分布を解消した。

\section{4 鉄の原子価分析 ${ }^{10,111}$}

ガラス試料を 400 メッシュ以下に粉砕し，一定量採取 し, 塩酸で加熱溶解させ, EDTAによるキレート滴定 を行うことによって, 鉄イオンの原子価比 $\left(R_{\mathrm{e}}=\right.$

Table 1. ( a ) Electrical properties, carrier number, jump distance of electron, polaron radius and

$\mathrm{TM}$-distance in the glasses of $40 \mathrm{Fe}_{2} \mathrm{O}_{3} \cdot 60 \mathrm{P}_{2} \mathrm{O}_{5}$. ( b ) $\Delta G$ and $\Delta H$ calculated from $G^{\prime}$ and $G^{\prime \prime}$.

Table l. a
\begin{tabular}{|c|c|c|c|c|c|c|c|c|c|}
\hline $\begin{array}{c}\mathrm{Re} \\
\text { ratio }\end{array}$ & $\begin{array}{c}\log \sigma 100^{\circ} \mathrm{C} \\
{[\mathrm{mho} / \mathrm{cm}]}\end{array}$ & $\left.\begin{array}{c}\Delta \mathrm{Hdc} \\
{[\mathrm{e} \mathrm{V}]}\end{array}\right]$ & $\begin{array}{l}\Delta \mathrm{Hac} \\
{[\mathrm{e} \mathrm{V}]}\end{array}$ & $\Delta \varepsilon$ & $\begin{array}{c}\mathrm{Nc} \\
{\left[10^{21}\right]}\end{array}$ & $\begin{array}{c}\mathrm{N} \\
{\left[10^{22}\right]}\end{array}$ & $\begin{array}{c}\lambda \\
{[\mathrm{A}]}\end{array}$ & $\begin{array}{c}\mathrm{r}_{\mathrm{p}} \\
{[\mathrm{A}]}\end{array}$ & $\begin{array}{c}\mathrm{R}_{\mathrm{d}} \\
(\mathrm{A})\end{array}$ \\
\hline 0.13 & -8.75 & 0.65 & 0.66 & 10.3 & 4.7 & 3.6 & 19.4 & 2.41 & 2.98 \\
0.17 & -8.36 & 0.60 & 0.50 & 11.5 & 6.4 & 3.6 & 17.6 & 2.17 & 2.69 \\
0.18 & -8.28 & 0.60 & 0.51 & 12.0 & 6.9 & 3.6 & 17.3 & 2.12 & 2.63 \\
0.25 & -7.77 & 0.52 & 0.49 & 12.0 & 10.3 & 3.6 & 14.1 & 1.85 & 2.30 \\
0.37 & -7.35 & 0.51 & 0.50 & 12.3 & 16.1 & 3.6 & 11.5 & 1.60 & 1.98 \\
0.52 & -7.26 & 0.51 & 0.53 & 13.5 & 22.6 & 3.6 & 10.1 & 1.43 & 1.77 \\
0.60 & -7.34 & 0.56 & 0.53 & 12.3 & 19.4 & 3.6 & 10.4 & 1.50 & 1.86 \\
\hline
\end{tabular}

Table 1. b

\begin{tabular}{|c|c|cc|}
\hline $\begin{array}{c}\text { Re } \\
\text { ratio }\end{array}$ & $\begin{array}{c}\Delta \mathrm{G} \text { (Low peak) } \\
\left(10^{8} \text { dyn } / \mathrm{cm}^{2}\right)\end{array}$ & $\begin{array}{r}\Delta \mathrm{H}^{\text {by }} \\
\text { (e V) }\end{array}$ \\
Low peak & High peak \\
\hline 0.13 & 1.47 & 0.50 & 1.58 \\
0.17 & 3.12 & 0.54 & 1.64 \\
0.25 & 5.13 & 0.50 & 1.73 \\
0.37 & 7.75 & 0.40 & - \\
\hline
\end{tabular}

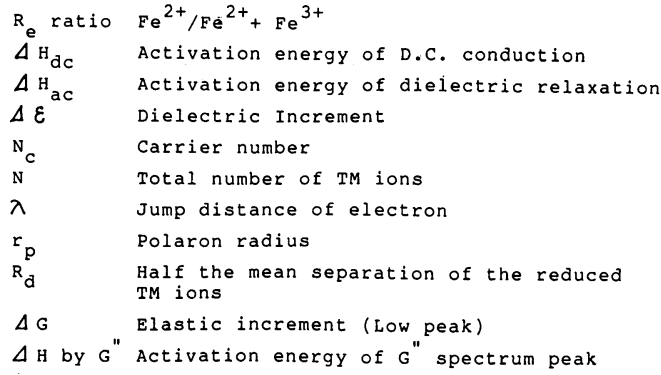

$\mathrm{R}_{\text {e ratio }} \mathrm{Fe}^{2+} / \mathrm{Fe}^{2+}+\mathrm{Fe}^{3+}$

$\triangle \mathrm{H}_{\mathrm{dc}} \quad$ Activation energy of D.C. conduction

$\Delta \varepsilon^{\mathrm{ac}} \quad$ Dielectric Increment

Polaron radius

Half the mean separation of the reduced

Elastic increment (Low peak)

$\Delta \mathrm{H}$ by $\mathrm{G} "$ Activation energy of $\mathrm{G}$ " spectrum peak 
$\left.\mathrm{Fe}^{2+} / \mathrm{Fe}^{2+}+\mathrm{Fe}^{3+}\right)$ を求めた。 以下, 原子価比 $\left(\mathrm{Fe}^{2+} /\right.$ $\left.\mathrm{Fe}^{2+}+\mathrm{Fe}^{3+}\right)$ を“ $R_{\mathrm{e}}$ 比” と記述する.

\section{3. 結果及び考察}

\section{1 直流導電率}

図 2 に $40 \mathrm{Fe}_{2} \mathrm{O}_{3} \cdot 60 \mathrm{P}_{2} \mathrm{O}_{5}$ ガラスの直流導電率の温度 依存性を示した。いずれの試料も次式を満足した。

$$
\sigma=\sigma_{0} \cdot \exp \left(\frac{-\Delta H_{\mathrm{dc}}}{R \cdot T}\right)
$$

したがって，（1）式から電気伝導の活性化エネルギー $\left(\Delta H_{\mathrm{dc}}\right)$ を求めることができる．表 1 に上式から計算し

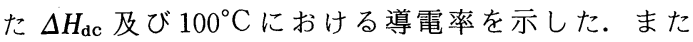
$100^{\circ} \mathrm{C}$ における導電率の $R_{\mathrm{e}}$ 比依存性を図 9 に示した。

$R_{\mathrm{e}}$ 比の増加に伴って導電率は上昇し, $R=0.5$ 付近に極 大を示した.

\section{2 誘電緩和}

図 3 に $40 \mathrm{Fe}_{2} \mathrm{O}_{3} \cdot 60 \mathrm{P}_{2} \mathrm{O}_{5}$ ガラスの誘電率 $\left(\varepsilon^{\prime}\right)$ 及び誘 電損率 $\left(\varepsilon^{\prime \prime}\right)$ の周波数依存性を示した. 左図は, $R_{\mathrm{e}}$ が 0.16, 右図は, $R_{\mathrm{e}}$ が 0.25 のものである. いずれのガラ スも, 誘電損率 $\left(\varepsilon^{\prime \prime}\right)$ は, 測定範囲内に一つのピークを 示した．ピーク強度は， $R_{\mathrm{e}}$ 比の増加とともに増大し， また, ピークは, 温度の上昇に伴って, 高周波数側へ移 動した. 誘電吸収 $(\varepsilon ")$ が極大を示す周波数 $\left(f_{\text {max }}\right)$ とそ の温度の逆数 $(1 / T)$ との関係は直線を示し, 次式で与 えられる。

$$
f_{\max }=f_{m 0} \cdot \exp \left(\frac{-\Delta H_{\mathrm{ac}}}{R \cdot T}\right)
$$

上式から誘電緩和の活性化エネルギー $\left(\Delta H_{\mathrm{ac}}\right)$ を求める ことができる. 表 1 に上式から計算した $\Delta H_{\mathrm{ac}}$ 及び誘電 緩和強度 $(\Delta \varepsilon)$ を示した。 また, 誘電緩和強度 $(\Delta \varepsilon)$ の $R_{\mathrm{e}}$ 比依存性を図 9 に示した. $R_{\mathrm{e}}$ 比の増加に伴って, $\Delta \varepsilon$ は上昇し, $R_{\mathrm{e}}=0.5$ で極大を示した. 誘電緩和と直 流電導との間には, 次式の関係が成立する

$$
\sigma=P \cdot 2 \pi \cdot \varepsilon_{0} \cdot \Delta \varepsilon \cdot f_{\max }
$$

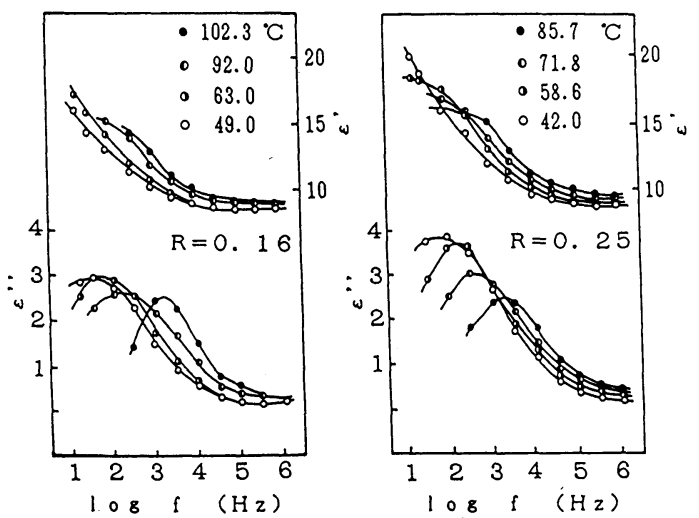

Fig. 3. Frequency dependence of $\varepsilon^{\prime}, \varepsilon^{\prime \prime}$ in the glasses of $40 \mathrm{Fe}_{2} \mathrm{O}_{5} \cdot 60 \mathrm{P}_{2} \mathrm{O}_{5}$.
ここで, $P$ は相関係数， $\varepsilon_{0}$ は真空の誘電率， $\Delta \varepsilon$ は誘電 緩和強度である．測定したすべての鉄りン酸塩ガラスは ほぼ $P=1$ を示した. 宗像らの報告によると ${ }^{13)}$, 電気伝 導に寄与する電荷のキャリア数 $\left(N_{\mathrm{c}}\right)$ は, 少数イオン $\left(\mathrm{Fe}^{2+}\right)$ の濃度から計算できる. すなわち，キャリア数 $\left(N_{\mathrm{c}}\right)$ は次式で表される.

$$
N_{\mathrm{c}}=\frac{C \cdot \rho \cdot N_{\mathrm{o}}}{A_{\mathrm{w}} \cdot 100}
$$

ここで, $C$ は $\mathrm{Fe}^{2+}$ イオンの濃度, $\rho$ は密度, $N_{\mathrm{o}}$ はアボ ガドロ数, $A_{\mathrm{w}}$ は鉄の原子量である. 表 1 にすべてのガ ラスのキャリア数 $\left(N_{\mathrm{c}}\right)$ 及び遷移金属イオン $[$ Transition Metal ion (TM イオン)] の総数 $(N)$ を示す. $N_{\mathrm{c}}$ の $R_{\mathrm{e}}$ 比依存性を図 9 に示す．キャリア数は, 直流導電率 と同様に $R_{\mathrm{e}}$ 比が 0.5 のとき極大を示し, 導電率が極大 となる理由が裏付けられた。 また，TM イオンの総数 $(N)$ とポーラロン半径 $\left(r_{\mathrm{p}}\right)$, 低原子価イオン $\left(\mathrm{Fe}^{2+}\right)$ の平均距離の $1 / 2\left(\boldsymbol{R}_{\mathrm{d}}\right)$ の関係は次式で示される ${ }^{14)}$.

$$
r_{\mathrm{p}}=\frac{1}{2} \cdot\left(\frac{\pi}{6 \cdot N}\right)^{1 / 3}, R_{\mathrm{d}}=\frac{1}{2} \cdot \frac{1}{\sqrt[3]{C \cdot N}}
$$

ここで， $R_{\mathrm{e}}$ は原子価比 $\left(\mathrm{Fe}^{2+} / \mathrm{Fe}^{2+}+\mathrm{Fe}^{3+}\right)$ である．表 1 にすべてのガラスの $r_{\mathrm{p}}, R_{\mathrm{d}}$ を示す． $r_{\mathrm{p}}$ 及び $R_{\mathrm{d}}$ は $R_{\mathrm{e}}$ 比すなわちキャリア数 $\left(N_{\mathrm{c}}\right)$ の増加に伴って減少し $R_{\mathrm{e}}$ $=0.5$ で極小を示した．ところで， $r_{\mathrm{p}}, R_{\mathrm{d}}$ 及び誘電緩和 の測定値から活性エネルギーを求めることができる．活 性化エネルギー $(W)$ は次式で与えられる ${ }^{14)}$.

$$
W=W_{\mathrm{H}}+\frac{1}{2} W_{\mathrm{D}}
$$

ここで， $W_{\mathrm{H}}$ はホッピングエネルギー， $W_{\mathrm{D}}$ は静電的不 規則エネルギーである。 また $W_{\mathrm{H}}$ は次式から得られる.

$$
\begin{aligned}
W_{\mathrm{H}} & =\frac{1}{2} W_{\mathrm{p}} \\
& =\frac{e^{2}}{16 \cdot \pi \cdot \varepsilon_{0}} \cdot\left(\frac{1}{\varepsilon_{\infty}}-\frac{1}{\varepsilon_{\mathrm{s}}}\right) \cdot\left(\frac{1}{r_{\mathrm{p}}}-\frac{1}{R_{\mathrm{d}}}\right)
\end{aligned}
$$

ここで， $W_{\mathrm{p}}$ はポーラロンエネルギー， $e$ は電荷， $\varepsilon_{0}$ は 真空の誘電率， $\varepsilon_{\infty}$ は高周波数域で一定值を示した誘電 率であり, $R_{\mathrm{e}}=0.25$ 試料の場合, $7 \mathrm{MHz}$ における $\varepsilon_{\infty}=$ $5 ， \varepsilon_{\mathrm{s}}$ は低周波数域で一定值を示した誘電率であり，30 $\mathrm{Hz}$ での $\varepsilon_{\mathrm{s}}=30$ を用いた. $W_{\mathrm{D}}$ は次式から得られる.

$$
W_{\mathrm{D}}=\frac{0.3 \cdot e^{2}}{4 \cdot \pi \cdot \varepsilon_{0} \cdot \varepsilon_{\mathrm{s}} \cdot R_{\mathrm{d}}}
$$

( 7 )，（8）式に $R_{\mathrm{e}}=0.25$ のそれぞれの值を代入し て活性化エネルギー $(W)$ を求めると, 約 $0.4 \mathrm{eV}$ とな り，実測值とほぼ等しい值を示した。

以上のことから, 電子が局在しているポーラロンの半 径は表 1 から見られるように $R_{\mathrm{e}}$ 比の増加とともに減少 を示し, 一方, ホッピングエネルギーと静電的不規則エ ネルギーの和として活性化エネルギーは $0.4 \mathrm{eV}$ を示し ている.このことは，ポーラロンに局在している電子を 
移動させるために $0.4 \mathrm{eV}$ 以上のエネルギーを与えなけ ればならないことを示している.

$\mathrm{Fe}^{2+}$ から $\mathrm{Fe}^{3+}$ への電子のジャンプ距離 $(\lambda)$ と誘電緩 和強度 $(\Delta \varepsilon)$ との間には, 次式の様な関係が成立する ${ }^{15)}$.

$$
\Delta \varepsilon=\frac{N \cdot e^{2} \cdot \lambda^{2}}{12 \cdot \varepsilon_{0} \cdot k \cdot T}
$$

ここで, $e$ は電荷, $\varepsilon_{0}$ は真空の誘電率, $k$ はボルツマン 定数， $T$ は絶対温度である.（9) 式から求めたジャン プ距離 $(\lambda)$ を表 1 に示す. $\lambda$ は $R_{\mathrm{e}}$ 比の増加とともに $R$ $=0.5$ 付近まで減少を示している. 以上の結果から, 誘 電緩和に寄与している電荷は, 直流電導に寄与している ものと同じであり, 鉄リン酸塩ガラスの誘電緩和に寄与 しているのは, 電子の運動であると考えられる. Hansen は $^{1)}$, 鉄リン酸塩ガラスの電気抵抗率において, $R_{\mathrm{e}}$ 比が 0.1 から 0.6 付近までのガラスは $\mathrm{n}$-type の半導 体であることを報告しており，著者らが測定した範囲内 では，電荷が電子であることは明らかである.

\section{3 内部摩擦の $R_{\mathrm{e}}$ 比依存性}

そこで，図 4 に電気的なキャリアとして電子を含む $40 \mathrm{Fe}_{2} \mathrm{O}_{3} \cdot 60 \mathrm{P}_{2} \mathrm{O}_{5}$ ガラスと, 電気的なキャリアを含ま

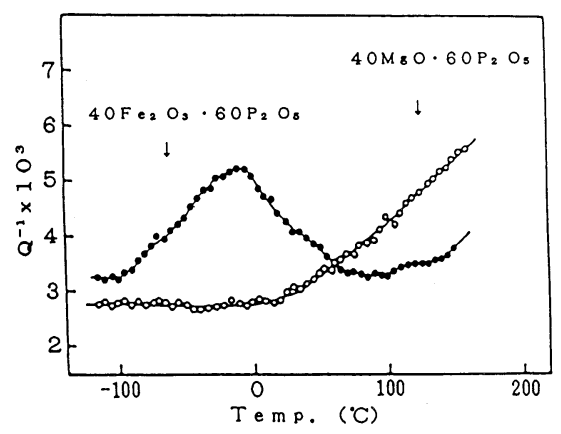

Fig.4. Temperature dependence of internal friction in the glasses of $40 \mathrm{Fe}_{2} \mathrm{O}_{3} \cdot 60 \mathrm{P}_{2} \mathrm{O}_{5}$ (O) and $40 \mathrm{MgO}$. $60 \mathrm{P}_{2} \mathrm{O}_{5}(\bigcirc)$.

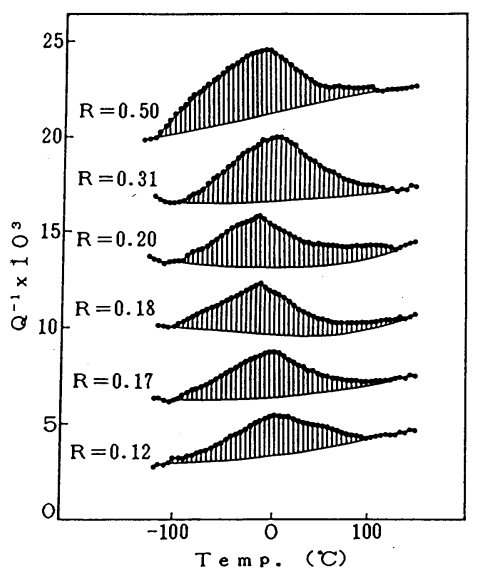

Fig. 5. Temperature dependence of internal friction in the glasses of $40 \mathrm{Fe}_{2} \mathrm{O}_{3} \cdot 60 \mathrm{P}_{2} \mathrm{O}_{5}$ having various ratio $R_{\mathrm{e}}=\mathrm{Fe}^{2+} / \mathrm{Fe}^{2+}+\mathrm{Fe}^{3+}$.
ない $40 \mathrm{MgO} \cdot 60 \mathrm{P}_{2} \mathrm{O}_{5}$ ガラスの内部摩擦スペクトルを比 較した. 電気的なキャリアを含まないマグネシウムリン 酸塩ガラスは, ピークを示さなかった.

図 5 にはガラス中の電子かホールの数, すなわち, $\mathrm{Fe}^{2+}$ と $\mathrm{Fe}^{3+}$ の比率 $\left(R_{\mathrm{e}}\right.$ 比) が異なる鉄リン酸塩ガラス の内部摩擦スペクトルを示した. 各スペクトル共, 内部 摩擦 $\left(Q^{-1} \times 10^{3}\right)$ は, 同じ程度の值で重なるため少しず つ上方へずらして示した， $R_{\mathrm{e}}$ 比の異なるすべてのガラ スにおいて, $0{ }^{\circ} \mathrm{C}$ 付近にブロードなピークが観察され $R_{\mathrm{e}}$ 比が $0.12 \sim 0.50$ ，すなわち，キャリアが電子である n-type の範囲内では, $R_{\mathrm{e}}$ 比の増加に伴ってピーク面積 及びピークの高さが増大した．このように $R_{\mathrm{e}}$ 比の異な る種々のガラスについて，同等にピーク面積を評価する ためには，規格化が必要となる．そこで本報告では，す べて図 6 に示す方法でピーク面積を求めた，上図の○印 は実測の内部摩擦 $\left(Q^{-1} \times 10^{3}\right)$ の值である。 ○印はラグ ランジェの補間法で計算したベースラインである. 実測 值から, 計算值を差し引くと下方のスペクトルが得られ る. 下方のスペクトルは, ガラスのネットワークの立ち

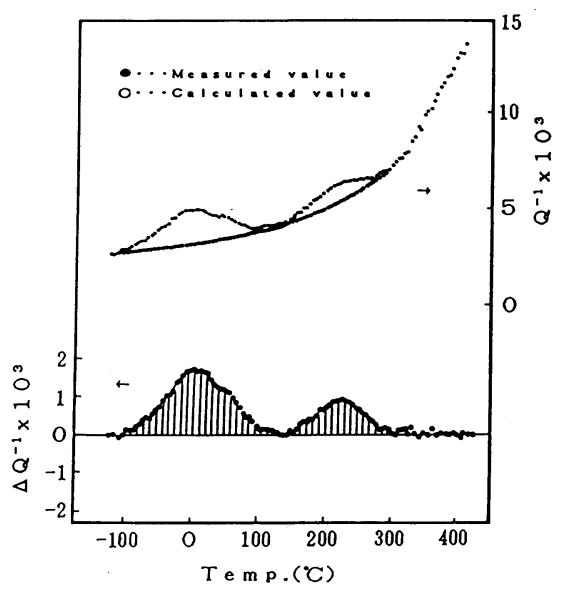

Fig. 6. Base line by interpolation method of Lagrange's for peak area of internal friction.

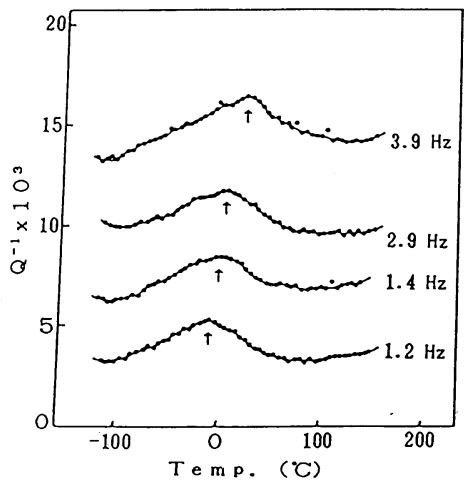

Fig. 7. Temperature dependence of internal friction on different frequencies in the glasses of $40 \mathrm{Fe}_{2} \mathrm{O}_{3} \cdot 60$ $\mathrm{P}_{2} \mathrm{O}_{5}$. 
上がりを除いた緩和現象のみの温度依存性を示している ことになる. シンプソンの台形法によって，そのピーク 部分の面積を求めた.

\section{4 内部摩擦の周波数依存性}

図 7 には $40 \mathrm{Fe}_{2} \mathrm{O}_{3} \cdot 60 \mathrm{P}_{2} \mathrm{O}_{5}\left(R_{\mathrm{e}}=0.13\right)$ ガラスの周波 数を変えて, 内部摩擦測定を行った結果を示した. 周波 数の増加とともに, ピークの極大を示す温度は, 高温度 側へ移動した．このピークの極大を示す温度と周波数の 関係は，直線を示した。

そこで, 図 8 に誘電吸収と内部摩擦で観察されたピー クの周波数-温度依存性を示した，その結果, 誘電吸収 で観察されたピークも同一直線上に乗っており，(2) 式を用いて図 8 の直線の傾きから計算で求めた活性化工 ネルギーは誘電吸収も内部摩擦も同じ值の約 $0.55 \mathrm{eV}$ を示した.このことから, 内部摩擦で観察されたピーク は, 誘電緩和現象で観察されたものと同様に $\mathrm{Fe}^{2+} \rightleftarrows \mathrm{Fe}^{3+}$ 間の電子ホッピングに基づいていると考え ることができる.

\section{5 諸物性の価数比依存性}

鉄リン酸塩ガラスの諸物性について, $R_{\mathrm{e}}$ 比に関する

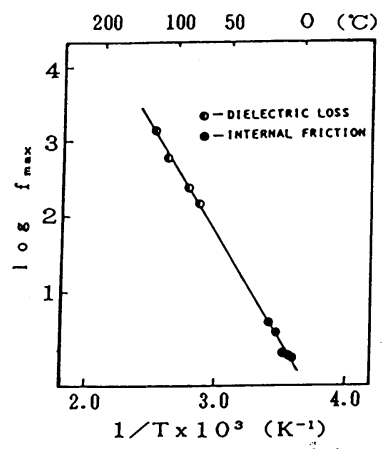

Fig. 8. Temperature dependence of frequency showing maxima in dielectric absorption and in internal friction in the glasses of $40 \mathrm{Fe}_{2} \mathrm{O}_{3} \cdot 60 \mathrm{P}_{2} \mathrm{O}_{5}$.

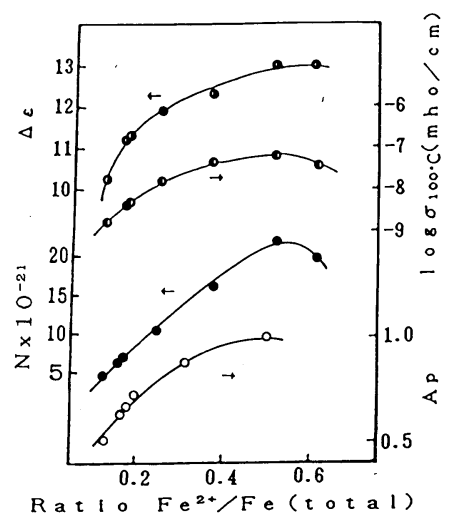

Fig. 9. Ratio $R_{\mathrm{e}}: \mathrm{Fe}^{2+} / \mathrm{Fe}$ (total) dependence of D. C. conductivity, dielectric increment, carrier number and relative peak area $\left(A_{\mathbf{p}}\right)$ for internal friction in the glasses of $40 \mathrm{Fe}_{2} \mathrm{O}_{3} \cdot 60 \mathrm{P}_{2} \mathrm{O}_{5}$.
依存性を示したのが図 9 である. $\Delta \varepsilon$ (誘電緩和強度), $\log \sigma_{100^{\circ} \mathrm{C}}\left(100^{\circ} \mathrm{C}\right.$ における導電率), $N$ (キャリア数), $A_{\mathrm{p}}$ (内部摩擦低温ピークのピーク面積) はすべて $R_{\mathrm{e}}$ 比 に対して同様の傾向を示している. すなわち， $R_{\mathrm{e}}=0.5$ 付近で極大を示す. 以上の結果から $\mathrm{Fe}^{2+}$ から $\mathrm{Fe}^{3+}$ へ の電子のホッピングが $R_{\mathrm{e}}=0.5$ すなわちドナーである $\mathrm{Fe}^{2+}$ とアクセプターである $\mathrm{Fe}^{3+}$ の数が等しいとき, 極 大を示すことが明らかとなった.これらの物性に寄与す るのは, いずれもキャリアとしての電子のホッピングで あり, 誘電緩和強度 $\Delta \varepsilon$ の場合は, 電子の移動に伴う電 気的なエネルギー損失が対応し, 内部摩擦の場合は, ポー ラロンに基づく力学的なエネルギー損失が対応してい る.

\section{6 內部摩擦のピーク面積と $\boldsymbol{R}_{\mathrm{e}}$ 比}

鉄リン酸塩ガラスのみならずバナジウムリン酸塩ガラ ス $^{16)}$, 分相性のバナジウムホウリン酸塩ガラスにおいて も， $R_{\mathrm{e}}$ 比依存のピークが観察された ${ }^{17)}$ そこで, 鉄リ ン酸塩系, バナジウムリン酸塩系, 及びバナジウムホウ リン酸塩系ガラスについて, その内部摩擦のピーク面積 をモル数で割って，その值を相対比にして， $R_{\mathrm{e}}$ 比依存 をプロットしたものが図 10 である. プロットはすべて $R_{\mathrm{e}}=0.5$ を極大にもつ規格化曲線上に乗った. したがっ て, 内部摩擦のピーク面積は, 遷移金属の種類によらず, キャリア濃度に対して, 図 10 に示すような一定の依存 性をもつことが明らかとなった。

\section{7 内部摩擦の定量化}

これまでは, 内部摩擦 $\left(Q^{-1} \times 10^{3}\right)$ という相対的な值 で議論してきた。更に定量性を持たせるためには形状因 子を加味する必要がある.

一般に逆つり型ねじり振り子のような振動系の運動方 程式は，次式で表される.

$$
I \frac{\mathrm{d}^{2} \theta}{\mathrm{d} t^{2}}+\frac{\eta^{\prime}}{A} \frac{\mathrm{d} \theta}{\mathrm{d} t}+\frac{G^{\prime}}{A} \theta+k \theta=0
$$

ここで, $I$ は振り子自体の慣性モーメント, $\eta^{\prime}$ は動的粘 性率, $G^{\prime}$ は動的弾性率, $k$ はつり線のねじれ定数, $A$

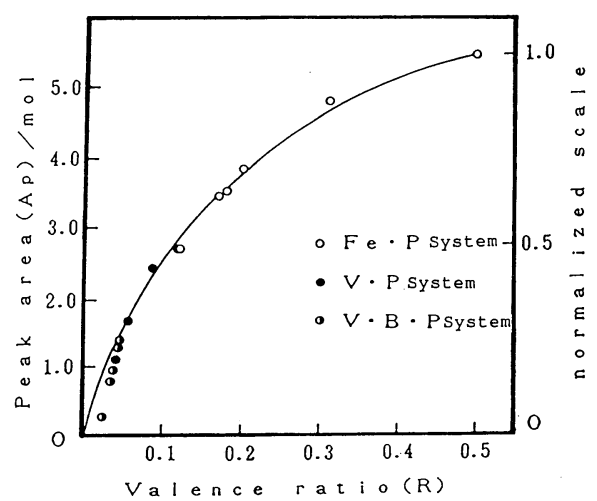

Fig. 10. Valence ratio $\left(R_{\mathrm{e}}\right)$ dependence of peak area $\left(A_{\mathrm{p}}\right) / \mathrm{mol}$ of internal friction. 
は形状因子, $\theta$ は角変位， $t$ は時間である.ここで, $(10)$ 式の両辺を $I$ で割って次式のようにおくと，

$$
2 \beta=\frac{\eta^{\prime}}{A I}, \quad n^{2}=\frac{G^{\prime}}{A I}+\frac{k}{I}
$$

（10）式は（12）式のように変形できる.

$$
\frac{\mathrm{d}^{2} \theta}{\mathrm{d} t^{2}}+2 \beta \frac{\mathrm{d} \theta}{\mathrm{d} t}+n^{2} \theta=0
$$

振り子を $\theta=0$ から $\theta=\theta_{0}$ までねじって放つという初 期条件のもとで，(12）式の微分方程式を解くと，次式 が得られる.

$$
\theta=\theta_{0} \cdot \operatorname{cosec} \phi \cdot \sin \left(\sqrt{n^{2}-\varepsilon^{2}} \cdot t+\phi\right) \cdot e^{-\beta t}
$$

（13）式はいわゆる自由減衰振動を示している．この式 より自由減衰振動の振動数 $(\nu d)$ 及び周期 $(T d)$ は次の ように表される.

$$
\nu d=\frac{\sqrt{n^{2}-\beta^{2}}}{2 \pi}, \quad T d=\frac{2 \pi}{\sqrt{n^{2}-\beta^{2}}}
$$

また，(12）式より対数減衰率 $(\Delta)$ は次のようになる. $\Delta=\beta \cdot T d$

(14)，（15）式より（11）式で定義した $n^{2}$ と $\beta$ は, 次 のように求められる.

$$
\begin{aligned}
& n^{2}=\frac{4 \pi^{2}}{T d^{2}}+\beta^{2}=\frac{4 \pi^{2}}{T d^{2}}+\frac{\Delta^{2}}{T d^{2}}=\frac{4 \pi^{2}+\Delta^{2}}{T d^{2}} \\
& \beta=\frac{\Delta}{T d}
\end{aligned}
$$

したがって，(11) 式より， $G^{\prime}$ を求めると次式となる.

$$
\begin{aligned}
G^{\prime} & =A I\left(n^{2}-\frac{k}{I}\right)=A I\left(\frac{4 \pi^{2}+\Delta^{2}}{T d^{2}}-\frac{k}{I}\right) \\
& =\frac{4 \pi^{2} A I}{T d^{2}}\left(1+\frac{\Delta^{2}}{4 \pi^{2}}\right)-A k
\end{aligned}
$$

また， $G^{\prime \prime}$ と $\eta^{\prime}$ との関係より $G^{\prime \prime}$ は次式となる。

$$
G^{\prime \prime}=\omega \eta^{\prime}=\frac{2 \pi \eta^{\prime}}{T d}=\frac{4 \pi A I \Delta}{T d^{2}}
$$

したがって， $G^{\prime}$ (動的弾性率) と $G^{\prime \prime}$ (損失弾性率) を 求めるためには, $I$ (振り子自体の慣性モーメント), $A$ (形状因子), $k$ (つり線のねじれ定数), $\Delta$ (対数减衰率)

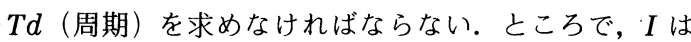
振り子自体の振動法により求められ，また， $A, k$ は試 料を装置に装着してしまえば決定できる值である。した がって, 温度依存性を示す $\Delta$ (対数減衰率) と $T d$ (周 期）を，各温度において測定すればよいことになる。

\section{8 内部摩擦スペクトル（定量）}

図 11 , 図 12 には，前章のように対数堿衰率 $(\Delta)$ 之 周期 $(T d)$ を各温度で測定することによって得られた動 的弹性率 $\left(G^{\prime}\right)$, 損失弾性率 $\left(G^{\prime \prime}\right)$ 及び内部摩擦 $\left(Q^{-1} \times\right.$ $\left.10^{3}\right)$ を示す. 図 11 には, $R_{\mathrm{e}}=0.13$ と $R_{\mathrm{e}}=0.17$ のガラ スのスペクトルを示した。 $G^{\prime}$ は $10^{9}$ のオーダーを示し， $G^{\prime \prime}$ は $10^{7}$ のオーダーを示した． $G^{\prime}$ は $G^{\prime \prime}$ のピーク温度 に変曲点を持つような曲線となり, 温度の上昇と共にそ の值は減少した、G" の二つのピークの間にあたる温度
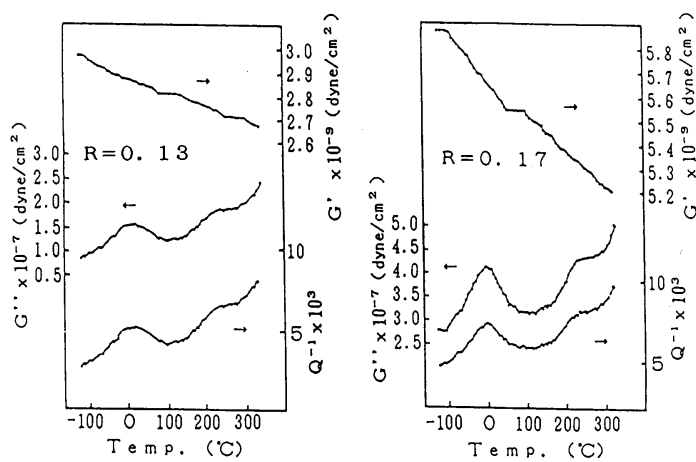

Fig. 11. Temperature dependence of $G^{\prime}, G^{\prime \prime}$ and in ternal friction in the glasses of $40 \mathrm{Fe}_{2} \mathrm{O}_{3} \cdot 60 \mathrm{P}_{2} \mathrm{O}_{5}\left(R_{\mathrm{e}}\right.$ $=0.13, R_{\mathrm{e}}=0.17$ ).

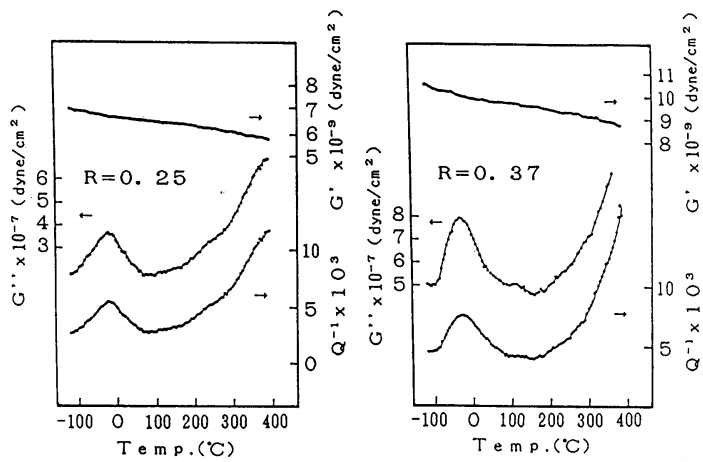

Fig. 12. Temperature dependence of $G^{\prime}, G^{\prime \prime}$ and internal friction in the glasses of $40 \mathrm{Fe}_{2} \mathrm{O}_{3} \cdot 60 \mathrm{P}_{2} \mathrm{O}_{5}\left(R_{\mathrm{e}}\right.$ $=0.25, R_{\mathrm{e}}=0.37$ ).

領域では, $G^{\prime} に$ にラットな部分があり，二つのピーク は独立に存在していることが分かる，次に，図 12 には， $R_{\mathrm{e}}=0.25$ と $R_{\mathrm{e}}=0.37$ のガラスのスペクトルを示した. なお， $G^{\prime}, G^{\prime \prime}$ のスケールは図 11 の 2 倍である. $R_{\mathrm{e}}=$ $0.13, R_{\mathrm{e}}=0.17$, 及び $R_{\mathrm{e}}=0.25$ では測定温度範囲内に 二つのピークを示したが, $R_{\mathrm{e}}=0.37$ では高温度側ピー クは消失した。低温度側ピークの高さとピーク面積は, 図 5 に示した内部摩擦 $\left(Q^{-1} \times 10^{3}\right)$ 之同樣に, $R_{\mathrm{e}}$ 比の増 加に伴って増大した. 更に, 低温度側ピーク部分の $G^{\prime}$ の変位加求めた緩和強度 $(\Delta G)$ を表 1 に示した. $\Delta G$ は $R_{\mathrm{e}}$ 比の増加とともに, 誘電緩和強度 $(\Delta \varepsilon)$ と同様に 増大した。一方, 高温度側ピークは, $R_{\mathrm{e}}$ 比の増加とと もに減少した。

周波数依存より検出されたピークの活性化エネルギー を表 1 に示した。低温度側ピークの活性化エネルギーは 約 $0.50 \mathrm{eV}$ となり, 図 8 の傾きから求めた活性化エネ ルギーとほぼ等しい值を示した．電気的性質及び内部摩 擦の定量化の結果から,低温度側ピークは, スモールポー ラロンを形成している $\mathrm{Fe}^{2+}$ の格子が，㸚じり振動に よってひずみを受け，トラップされた電子がホッピング するためと考えられた，一方，高温度側ピークの活性化 
エネルギーは, 約 $1.60 \mathrm{eV}$ とった.これは, 約 37 $\mathrm{kcal} / \mathrm{mol}$ に相当する. Zdaniewski ら ${ }^{18)}$ は，アルカリを 含む $\mathrm{SiO}_{2}$ 系の 2 成分あるいは 3 成分系ガラスの内部摩 擦のレビューの中でいずれのガラスも低温度側と高温度 側に二つのピークが観察されると述べている．低温度側 ピークの活性化エネルギーは $15 \sim 25 \mathrm{kcal} / \mathrm{mol}$ の值を持 ち, アルカリイオンの拡散に基づいており，一方，高温 度側ピークの活性化エネルギーが，30〜 $40 \mathrm{kcal} / \mathrm{mol}$ 程 度の值を持っていることを指摘した。この活性化エネル ギーに相当する過程は酸素イオンとプロトン, アルカリ イオンとプロトン, 混合アルカリの相互作用そして非架 橋酸素イオンの運動等であろうと考えた. 一方, 坂村ら は ${ }^{19)}, \mathrm{Na}_{2} \mathrm{O}-\mathrm{H}_{2} \mathrm{O}-\mathrm{P}_{2} \mathrm{O}_{5}$ 系ガラスの内部摩擦を測定し, アルカリイオンを含まない $\mathrm{P}_{2} \mathrm{O}_{5}$ ガラスの内部摩擦にも 高温度ピークが見られることから, 高温度側ピークがア ルカリイオンと $\mathrm{H}^{+}$イオンの相互作用に基づくという $\mathrm{Day}^{20)}$ の説明は, 困難であることを指摘し, 恐らく非架 橋酸素が関係していると考えた。 また，坂村ら ${ }^{21)}$ は $\mathrm{Na}_{2} \mathrm{O}-\mathrm{Al}_{2} \mathrm{O}_{3}-\mathrm{SiO}_{2}$ 系ガラスのような単一アルカリガラ スにも高温度側ピークを見いだし，その緩和機構として 非架橋酸素単独ではなく，アルカリイオンの動きも関係 していると考えた. 著者らが測定したのは, 鉄リン酸塩 ガラスであり，アルカリイオンは含まれていない。した がって, 前記の活性化エネルギーの值及びピークの $R_{\mathrm{e}}$ 比依存性等から, 高温度側ピークはプロトンと非架橋酸 素イオンの相互作用に基づくと考えられた.

\section{9 低温側ピークの発生機構}

ガラスのように乱れた構造でも短距離規則が保持されて いれば，図13のようなバンド構造が成立することが理 論的に示されている. しかし, 図のような局在準位がで きてバンドの縁がぼやける．ガラスでは，このような禁 止帯内の深い準位がトラップとして働き, また，原子内 の波動関数の重なり合いが少ないため, 伝導帯の幅は狭 く, バンド内での電子の速度は小となっている，そのた め, 電子が特定のイオン (本系ガラスでは, $\mathrm{Fe}^{2+}$ イオン) 上に格子振動の周期に比べ十分長い時間 $\left(>10^{-12} \mathrm{~s}\right)$ 滞 在する. 一例として, 図 13 にポーラロンを示した. 分 極場に捕らえられた電子は自由に動けなくなり，図のよ うなポーラロンを作っている. $\mathrm{Fe}^{2+}$ 上に局在した電子

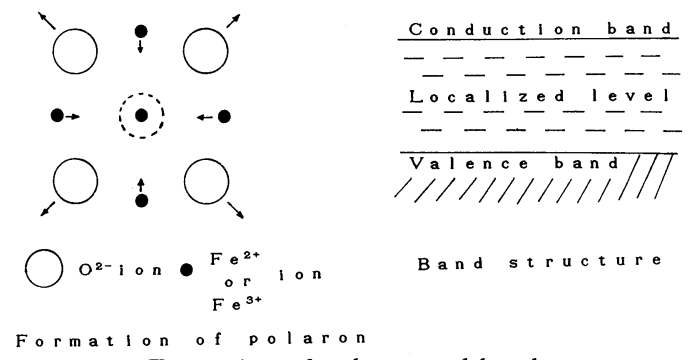

Fig. 13. Formation of polaron and band structure.
を動かすには, 格子振動の助けが必要となる.この場合, 電子は自分で動くというより格子振動に導かれ, ホッピ ングする. すなわち, 電子伝導性ガラスにおいて, 振り 子の振動に基づくねじり弾性エネルギーにより, 力学的 なひずみが試料に加わり局在準位間のエネルギーレベル が変化し, この変化と熱活性化プロセスによりポーラロ ンに基づくホッピングが起こって内部摩擦が生じ, 格子 振動が更に激しくなると考えられる．この場合，内部摩 擦には,すべてのポーラロンが関与しているのではなく, ガラス中のネットワーク構造の欠陥（ある弱い構造をも つ部分) 等に生成した特定の形状のポーラロンが関与し ていると考えられる.

\section{4. 総 括}

$40 \mathrm{Fe}_{2} \mathrm{O}_{3} \cdot 60 \mathrm{P}_{2} \mathrm{O}_{5}$ ガラスの電気的性質（直流導電率 • 誘電特性) 及び内部摩擦の測定を行った結果, 次のよう な結論を得た。

（1）内部摩擦において, 形状因子を加味した動的弾 性率 $\left(G^{\prime}\right)$, 損失弾性率 $\left(G^{\prime \prime}\right)$ という定量值を得ること ができた. $R_{\mathrm{e}}$ 比が 0.13 から 0.37 までの範囲において, $G^{\prime}$ は $3.0 \times 10^{9}$ から $1.0 \times 10^{10}\left(\mathrm{dyn} / \mathrm{cm}^{2}\right)$ まで変化し, $G^{\prime \prime}$ は, $1.0 \times 10^{7}$ から $5.0 \times 10^{7}\left(\mathrm{dyn} / \mathrm{cm}^{2}\right)$ まで変化した. また $G^{\prime}$ と $G^{\prime \prime}$ は典型的な緩和現象の形でスペクトルが 得られた。

（2）電気的性質測定の結果から, $R_{\mathrm{e}}$ 比の増加に伴っ て, 直流導電率, 誘電緩和強度, キャリア数は上昇して $R=0.5$ で極大を示し, 平衡位置間距離, ポーラロン半 径, 遷移金属イオン間距離は減少して $R_{\mathrm{e}}=0.5$ で極小 を示した. 一方, 内部摩擦測定の結果から, $R_{\mathrm{e}}$ 比の増 加に伴って, 低温度側ピークの緩和強度, ピーク面積, ピークの高さは上昇して $R_{\mathrm{e}}=0.5$ で極大を示し, 電気 的性質との相関性が見いだされた.

（3）誘電緩和及び内部摩擦においてピークの極大を 示す周波数 $f_{\max }$ 対 $1 / T$ プロットが，全く同一直線で表 すことができた。このことは, 両者が同一の活性化エネ ルギー $(0.55 \mathrm{eV})$ を持ち, 直流電導の活性化エネルギ一 と等しい値を得た.

（4）電気的なキャリアとして電子を含む鉄りン酸塩 ガラスは, 内部摩擦のピークを示し, 電気的なキャリア を含まないマグネシウムリン酸塩ガラスは, ピークを示 さなかった。

（5）鉄リン酸塩ガラスのみならず，バナジウムを含 むガラス等の内部摩擦を検討した結果, ピーク面積をそ の遷移金属イオンのモル数で割って得られた值は, $R_{\mathrm{e}}$ 比に対して一定の規格化曲線上に乗り，ピーク面積は遷 移金属の種類によらず $R_{\mathrm{e}}$ 比に対して一定の依存性を持 つことを見いだした。

以上の結果から, 内部摩擦において観察された低温度 
側ピークは, 力学的なひずみが試料に加わり局在準位間 のエネルギーレベルが変化し，この変化と熱活性化プロ セスによりポーラロンに基づくホッピングが起こって内 部摩擦が生じると考えられた。一方高温度側ピークは, プロトンと非架橋酸素との相互作用によるものであると 考えられた。

\section{文献}

1) K. W. Hansen, J. Electrochem. Soc., 112, 994 (1965).

2) J. G. Vaughan and D. L. Kinser, J. Am. Ceram. Soc., 58, 326-29 (1975).

3）土谷敏雄, 渡辺一博, Nerw Glass Technology, 4, 14-20 (1985).

4) E.H. Verstegen and Delbert E. Day, J. Non-Cryst. Solids, 14, 142-56 (1974).

5）今岡 稔, 坂村博康, 窯協, 87, 387-94 (1979).

6) 坂村博康, 戸塚光男, 安井 至, 今岡 稔, 窯協, 89 , 603-07 (1981).

7) W. Chomka, O. Gzowski, L. Murawski and D. Samato- wictz, J. Phys. C, 11, 3081 (1978).

8) A. K. Bandyopadhyay, J. Phalippou and J. Zarzycki, J. Non-Cryst. Solids, 57, 41-48 (1983).

9）土谷敏雄, 森谷太郎, 害協, 81, 303-09 (1973).

10）上野景平, “キレート滴定法”, 南江堂 (1979) p. 317.

11）田中信行，杉 晴子，“錯体形成反応”, 産業図書 (1973) p. 126.

12）並河 洋, 中島達二, 第 4 回窯業協会ガラス部会討論会 予稿集 (1968) p. 13.

13）宗像元介, “新しい工業材料の科学”, B series 15, 金原 出版社 (1968) p. 1 .

14) J. O. Isard, J. Non-Cryst. Solids, 42, 371-80 (1980).

15) H. Fröhlich, “Theory of Dielectrics”, Oxford (1958).

16）土谷敏雄, 音成光哉, 窯業協会昭和 60 年年会予稿集 (1985) p. 97-98.

17）土谷敏雄, 音成光哉, 第 23 回窯業基礎討論会予稿集 (1985) p. 77.

18) W. A. Zdaniewski, G. E. Rindone, J. Mater. Sci., 14, 763-75 (1979).

19）坂村博康, 今岡 稔, 窯協, 83, 460-64 (1975).

20) D.E. Day, J. Am. Ceram. Soc., 57, 530-33 (1974).

21）坂村博康, 安井 至, 窯協, 93, 165-69(1985). 